\title{
A chromatographic method for the production of a human immunoglobulin G solution for intravenous use
}

K. Tanaka, E. Sawatani, E.M. Shigueoka, T.C.X.B. Campos, H.C. Nakao, G.A. Dias, R.K. Fujita and F. Arashiro
Divisão de Produção e Desenvolvimento Industrial, Fundação Pró-Sangue Hemocentro de São Paulo, São Paulo, SP, Brasil

\section{Correspondence \\ K. Tanaka \\ Divisão de Produção e \\ Desenvolvimento Industrial \\ Fundação Pró-Sangue Hemocentro \\ de São Paulo \\ Av. Enéas C. Aguiar, 155, 10 andar \\ 05403-000 São Paulo, SP \\ Brasil}

Publication supported by FAPESP.

Received April 28, 1998

Accepted August 18, 1998

\begin{abstract}
Immunoglobulin $\mathrm{G}(\operatorname{IgG})$ of excellent quality for intravenous use was obtained from the cryosupernatant of human plasma by a chromatographic method based on a mixture of ion-exchange, DEAE-Sepharose FF and arginine Sepharose 4B affinity chromatography and a final purification step by Sephacryl S-300 HR gel filtration. The yield of 10 experimental batches produced was $3.5 \mathrm{~g} \mathrm{IgG}$ per liter of plasma. A solvent/detergent combination of $1 \%$ Tri (n-butyl) phosphate and $1 \%$ Triton X-100 was used to inactivate lipid-coated viruses. Analysis of the final product ( $5 \%$ liquid $\mathrm{IgG}$ ) based on the mean for 10 batches showed $94 \%$ monomers, $5.5 \%$ dimers and $0.5 \%$ polymers and aggregates. Anticomplementary activity was $0.3 \mathrm{CH}_{50} / \mathrm{mg} \mathrm{IgG}$ and prekallikrein activator levels were less than $5 \mathrm{IU} / \mathrm{ml}$. Stability at $37^{\circ} \mathrm{C}$ for 30 days in the liquid state was satisfactory. IgG was stored in flasks (2.5 $\mathrm{g} / \mathrm{flask}$ ) at 4 to $8^{\circ} \mathrm{C}$. All the characteristics of the product were consistent with the requirements of the 1997 Pharmacopée Européenne.
\end{abstract}

\section{Introduction}

Commercially available liquid or lyophilized immunoglobulins $\mathrm{G}(\mathrm{IgG})$ are produced from pooled human plasma from a large number of donors, usually more than one thousand, so that a wide variety of antibodies will be present in the product (1). Several production processes are employed, most of them based on the method of Cohn (2), i.e., fractionation with cold ethanol, with polyethyleneglycol (PEG) precipitation (3) or purification by ion-exchange and gel filtration chromatography $(4,5)$. The IgG isolated from human plasma in the 1940's and 1950 's by the method of fractionation with cold ethanol of Cohn and Oncley $(2,6,7)$ was suitable for intramuscular use and could not be administered intravenously because of undesirable effects due to the modifications in the IgG molecule, such as aggregates resulting from the fractionation process with ethanol and other agents which increased its anticomplement activity $(8,9)$. 
Thus, the major goal of $\mathrm{IgG}$ producers was to develop methods that would guarantee intravenous tolerance, eliminating or preventing the aggregation of molecules without affecting the activity of the antibodies present in the IgG preparation. The first process for the production of intravenous (iv) IgG was based on treatment of IgG with a quantity of pepsin (10) or plasmin (11) that caused enzymatic cleavage of IgG molecules. This process, corresponding to the preparation of first-generation $i v \mathrm{IgG}$, is today considered to be obsolete (9).

Specific structural changes of IgG were introduced in the enzymatic methods to reduce anticomplementary activity. The products thus obtained usually have reduced in vivo survival times and their continuous use may cause an antigen response depending on the enzyme used (12). The second-generation $i v$ IgG consisted of chemically modified preparations with more or less impaired Fc-related effector functions (9). From 1975 to 1989 , the chemical modification of the protein was probably the most successful approach to the preparation of $i v \operatorname{IgG~(12).~}$ The reagents used for this modification range from B-propiolactone (13) to reducing/alkylating agents $(12,14)$, reducing/amidating agents (15) and reducing/sulfonating agents (16).

Today, all of these preparations are being replaced with third-generation products containing intact $\operatorname{IgG}$ molecules which retain effector functions. The latest generation includes preparations that are free of complement-activating aggregates thanks to the use of small or trace amounts of pepsin, $\mathrm{pH} 4.0$, PEG and bulk adsorption with ion-exchange gel (9). This development was encouraged by the fact that the chromatographic method provides a safe and effective $i v \operatorname{IgG}$ product meeting the 1982 requirements of the World Health Organization Committee (17). The choice of a third-generation preparation which exhibits all the functions of the IgG molecule will be determined on the basis of safety in terms of viral transmission and absence of contaminants. Furthermore, the preparation should contain a normal distribution of IgG subclass molecules and have a half-life after infusion (9) which is in the physiological range of 21 to 36 days.

\section{Material and Methods}

\section{Production equipment}

Pharmacia liquid chromatography equipment was employed using a Bio Process controller (Uppsala, Sweden). The following columns were used: step 1, desalting, gel filtration on Sephadex G-25, 1 column, model BPSS 400/600 (60 cm in height by $40 \mathrm{~cm}$ in diameter). Step 2, anion-exchange DEAESepharose FF, 1 column, model PS-370/15 $(15 \mathrm{~cm}$ in height and $37 \mathrm{~cm}$ in diameter). Step 3, affinity gel Arginine Sepharose 4B $(40 \%)+$ anion-exchange DEAE-Sepharose FF (60\%), 1 column, model PS-370/15 (15 $\mathrm{cm}$ in height by $37 \mathrm{~cm}$ in diameter) and cation-exchange CM-Sepharose FF, 1 column, model Index 200/500 (15 cm in height and $20 \mathrm{~cm}$ in diameter). Step 4, cation-exchange CM-Sepharose FF, 1 column, model Index 200/500. Step 5, gel filtration on Sephacryl S-300, 1 column, model BPG 200/ 950 ( $95 \mathrm{~cm}$ in height and $20 \mathrm{~cm}$ in diameter).

Other instruments used were a tangential flow ultrafiltration Pellicon cassette system and a filtration system with a stainless steel sanitary filter holder, $293 \mathrm{~mm}$ in diameter (Millipore, Bedford, MA, USA), and a continuous flow centrifuge model AG BKA-6 (Westphalia Separator, Oeld, Germany).

Details about the buffer solutions are given in Table 1.

\section{Preparation of immunoglobulin G}

Approximately 1200 human plasma bags stored at $-30^{\circ} \mathrm{C}$ were thawed at a temperature of 2 to $4^{\circ} \mathrm{C}$ in order to form a 200-1 pool. Thawed plasma was centrifuged at $2^{\circ} \mathrm{C}$ to 
obtain a cryoprecipitate to be used for the production of factor VIII. The supernatant of the cryoprecipitate was cleared by filtration through a 30-S depth filter (Zeta Plus, Cuno, Meriden, CT, USA) and desalted with coarse Sephadex G-25 filtration gel on a BPSS 400/ 600 column using $5 \mathrm{mM}$ sodium acetate as elution solution. The $\mathrm{pH}$ was adjusted to 5.2 with $1 \mathrm{M} \mathrm{CH}_{3} \mathrm{CO}_{2} \mathrm{H}$ and the protein solution (410 1) was allowed to stand overnight in a cold chamber at $4{ }^{\circ} \mathrm{C}$ for euglobulin precipitation. On the following day the preparation was centrifuged at $4^{\circ} \mathrm{C}$ to remove the precipitated euglobulins and the supernatant was cleared by filtration. The $\mathrm{pH}$ was readjusted to 5.2 with $1 \mathrm{M} \mathrm{CH}_{3} \mathrm{CO}_{2} \mathrm{H}$ and conductivity was adjusted to $1.4 \mathrm{mS} / \mathrm{cm}$ with $\mathrm{NaCl}$. The sample was applied to a PS-370/
15 column containing DEAE-Sepharose FF in order to separate gamma-globulin (unadsorbed) from other plasma proteins such as albumin, etc.

The gamma-globulin fraction was submitted to chromatography for the preparation of $\mathrm{IgG}$ as described below. The albumin fraction was further purified by a chromatographic method (18). The $\mathrm{pH}$ of the gammaglobulin fraction (480 l) was adjusted to $\mathrm{pH}$ 6.0 with $1 \mathrm{M} \mathrm{NaOH}$ and conductivity was adjusted to $1.4 \mathrm{mS} / \mathrm{cm}$. The fraction was then applied to two columns, PS-370/15 and Index 200/500, coupled in series. The first column was packed with a mixture of two gels, 40\% arginine Sepharose 4B and 60\% DEAE-Sepharose FF, and the second with 8 1 of CM-Sepharose FF gel.

Table 1 - Buffer solutions used.

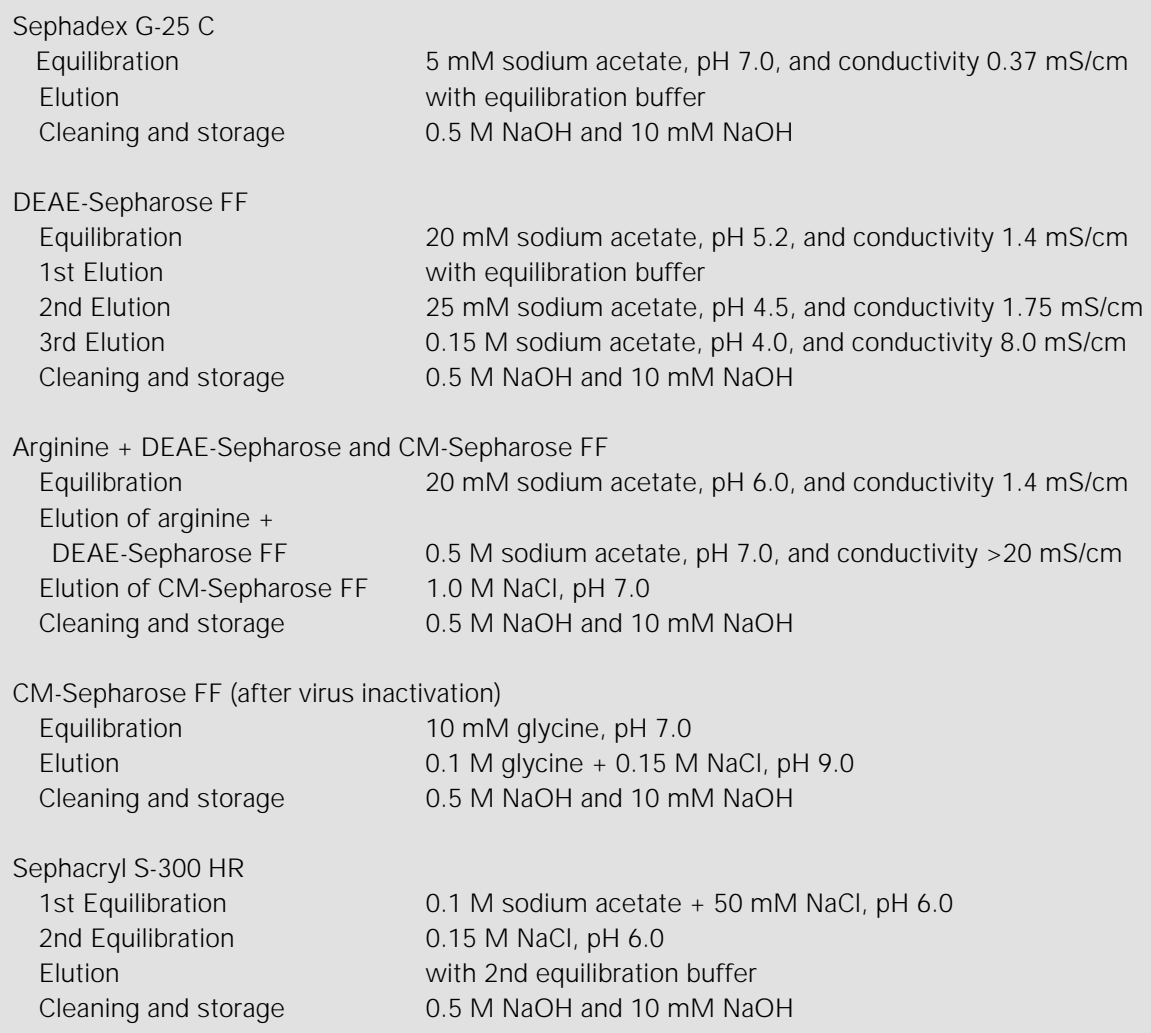


The proteins not of interest for the present study, $\operatorname{IgM}, \operatorname{Ig} \mathrm{A}$, transferrin, etc, were adsorbed to the first column. IgG was adsorbed to the second column and eluted and concentrated to $5 \%(\mathrm{w} / \mathrm{v})$ using the

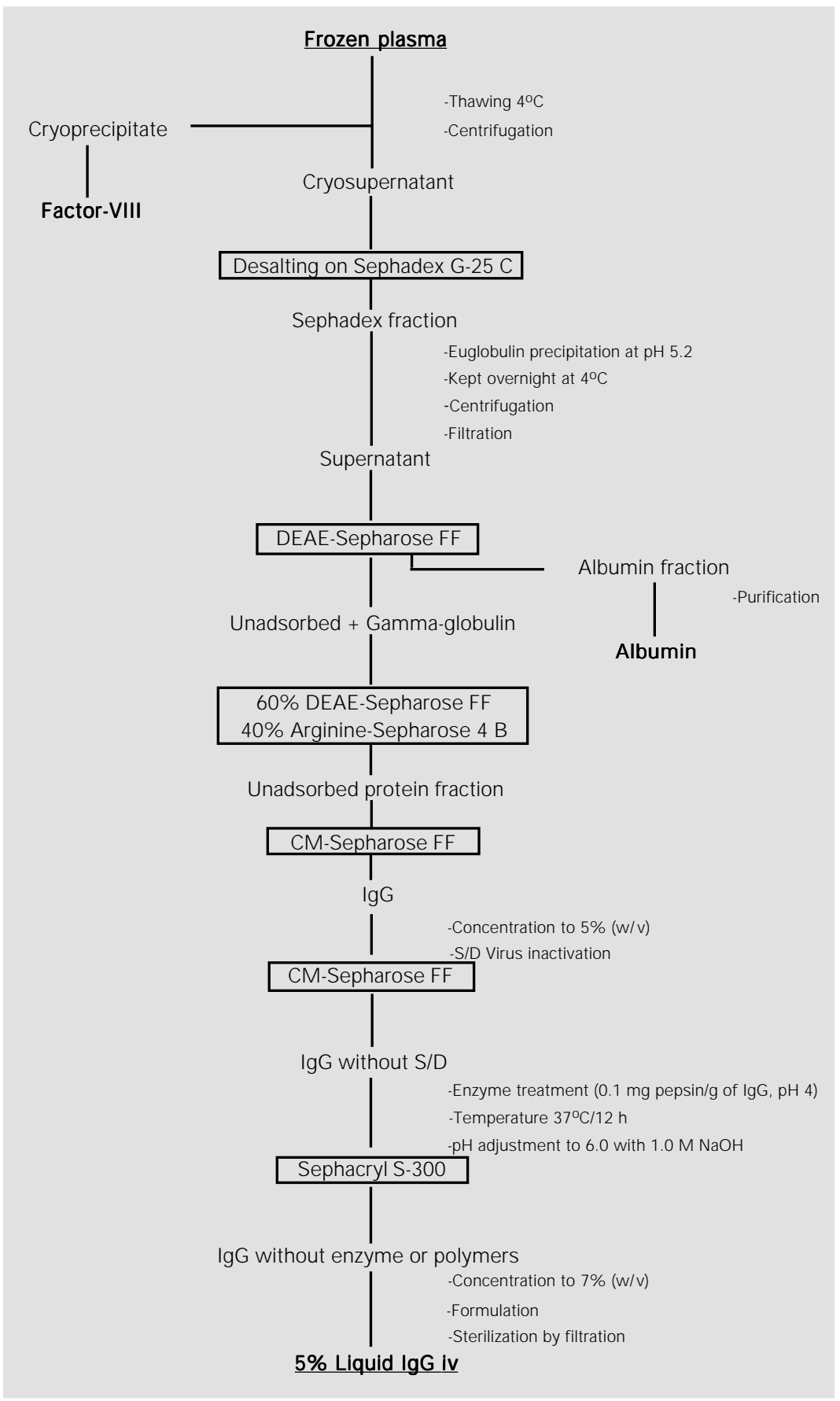

Figure 1 - Flow diagram for the production of liquid intravenous IgG.
Pellicon Cassette System 30,000 NMWL. The $\mathrm{pH}$ of the IgG solution (16 1) was adjusted to 5.5 and the material was submitted to viral inactivation with a solvent/detergent combination (19), i.e., $1 \%$ Tri (n-butyl) phosphate and $1 \%$ Triton $\mathrm{X}-100$ at $35^{\circ} \mathrm{C}$ for $10 \mathrm{~h}$. After viral inactivation, the solvent/detergent combination was removed by ion-exchange chromatography on CM-Sepharose FF in an Index 200/500 column containing 8 1 of gel. The IgG solution was concentrated to $7 \%$, pepsin was added $(0.1 \mathrm{mg} / \mathrm{g}$ protein $)$, $\mathrm{pH} 4.0$, and the solution was heated at $37^{\circ} \mathrm{C}$ for $10 \mathrm{~h}$. The preparation was cooled to $20^{\circ} \mathrm{C}$ and then applied to a BPG 200/950 column containing 201 of Sephacryl S-300 HR filtration gel to remove the aggregated $\mathrm{IgG}$ molecules and pepsin. The eluted IgG solution was concentrated to $6.5 \%$ and then formulated as follows: the $\mathrm{pH}$ was adjusted to 5.0 with $1 \mathrm{~N} \mathrm{HCl}$, the conductivity to 9 to 10 $\mathrm{mS} / \mathrm{cm}$ with solid $\mathrm{NaCl}$, and $7.5 \%(\mathrm{w} / \mathrm{v})$ maltose and $0.1 \mathrm{M}$ glycine were added as stabilizers $(12,20)$. The material was sterilized by filtration through a $0.22-\mu \mathrm{m}$ membrane (Millipore) and the final product (14 1), containing $5 \%$ protein $(\mathrm{w} / \mathrm{v})$, was bottled in 50-ml type I (neutral) flasks, with $2.5 \mathrm{~g}$ IgG per flask and was stored at 4 to $8^{\circ} \mathrm{C}$ (see Figure 1).

\section{Analytical methods}

The characteristics of normal liquid 5\% IgG for intravenous use were evaluated by the methods described in the Pharmacopée Européenne (1) and in Regulation No. 2.419 of $12 / 17 / 1996$ of the Brazilian Ministry of Health.

The immunochemical tests were carried out by cellulose acetate electrophoresis, by the micro-Ouchterlony method and by immunoelectrophoresis using anti-total human protein and anti-animal protein antisera of domestic species such as horses, cows and sheep. Protein concentration was determined by the biuret method, $\mathrm{pH}$ was measured by 
diluting to $1 \%$ in a $0.9 \%$ sodium chloride solution, and anti-A and anti-B hemagglutinins were determined by the indirect Coombs method. The presence of other plasma proteins such as $\operatorname{IgA}$ and $\operatorname{IgM}$ and of the $\operatorname{IgG}$ subclasses IgG1, IgG2, IgG3 and IgG4 was determined by radial immunodiffusion on Bindarid plates (The Binding Site Inc., San Diego, CA, USA).

Anticomplementary activity was determined by the method of Mayer using guinea pig complement and sheep red cells. The prekallikrein activator was determined using the S2302 chromogenic substrate of Chromogenix (Mölndal, Sweden).

The biological safety of the product was evaluated by tests for the detection of antiHIV, anti-HTLV-1 and 2, anti-HCV, and $\mathrm{HB}$ antigens at the Serology Laboratory of Fundação Pró-Sangue Hemocentro de São Paulo. Sterility was evaluated by the Steritest membrane method (Sterility Testing System, Millipore). Pyrogenicity and toxicity were tested at Medlab, São Paulo, Brazil.

The distribution of monomers, dimers and polymers was evaluated by HPLC, and anti-polio I, II and III, anti-measles and antiherpes activities were determined at Instituto Adolfo Lutz, São Paulo, Brazil. Anti-rubeola, anti-CMV and anti-streptolysin $\mathrm{O}$ activities were determined at the Immunology Laboratory of IAMSPE, São Paulo, Brazil. Stability was evaluated by incubating the preparation at $57^{\circ} \mathrm{C}$ for $4 \mathrm{~h}$ and observing the presence of jelling.

\section{Results and Discussion}

The size distribution of the product, evaluated by HPLC, indicated $94 \%$ monomers, $5.5 \%$ dimers and $0.5 \%$ polymers, corresponding to standard values. The profile of the IgG molecule did not show any alterations when the $\mathrm{IgG}$ preparation was incubated at $37^{\circ} \mathrm{C}$ for one month; the anticomplementary activity was $0.3 \mathrm{CH}_{50} / \mathrm{mg} \mathrm{IgG}$, in agreement with the specifications that determine a value of less than $1 \mathrm{CH}_{50} / \mathrm{mg} \mathrm{IgG}$, and the functional activity of $\mathrm{Fc}$ was unchanged, presenting an index of 125 to $128 \%$ of $\mathrm{Fc}$, meeting the recommendation of Pharmacopée Européenne, which requires $>60 \%$. On the basis of these evaluations, we concluded that the product contained intact molecules. The subclasses determined were $\operatorname{IgG} 1=65.6 \%, \mathrm{IgG} 2$ $=28.7 \%, \mathrm{IgG} 3=4.2 \%$, and $\mathrm{IgG} 4=1.4 \%$, with no significant variations compared to normal plasma. For prekallikrein activator (PKA) determination we used a reference PKA from the FDA and the S2302 chromogenic substrate of Chromogenix. Values of less than $5 \mathrm{IU} / \mathrm{ml} 5 \%$ (w/v) $\mathrm{IgG}$ were obtained, well below the specification limit of $35 \mathrm{IU} / \mathrm{ml}$ of PKA. The remaining data which characterize the product are presented in Tables 2 and 3, and cellulose acetate

Table 2 - Characteristics of liquid intravenous IgG.

$\mathrm{N}=10$. ND, Not detected. *Pharmacopée Européenne (1).

\begin{tabular}{|c|c|c|}
\hline Analysis & Results & Specifications* \\
\hline Protein concentration & $5.0 \pm 0.2 \%$ & $>90$ to $<110 \%$ \\
\hline pH determination & $4.5-5.0$ & $4.0-7.4$ \\
\hline PKA determination & $<5.0 \mathrm{IU} / \mathrm{ml}$ & $<35 \mathrm{IU} / \mathrm{ml}$ \\
\hline Purity (electrophoresis) & $>99 \%$ & $>95 \%$ \\
\hline $\lg A$ & ND & - \\
\hline $\operatorname{Ig} M$ & ND & - \\
\hline Anti-A hemagglutinin & $\leq 1: 8$ & $<1: 64$ \\
\hline Anti-B hemagglutinin & $\leq 1: 8$ & $<1: 64$ \\
\hline Anticomplementary activity & $<0.3 \mathrm{CH}_{50} / \mathrm{mg}$ IgG & $<1 \mathrm{CH}_{50} / \mathrm{mg} \operatorname{lgG}$ \\
\hline Aluminum & $<20 \mu \mathrm{g} / \mathrm{ml}$ & - \\
\hline Fc function & $125-128 \%$ & $>60 \%$ \\
\hline \multicolumn{3}{|l|}{ Molecular distribution } \\
\hline Monomers & $94.0 \%$ & mono + dimers $=90 \%$ \\
\hline Dimers & $5.5 \%$ & \\
\hline Polymers & $0.5 \%$ & polymers $<3 \%$ \\
\hline \multicolumn{3}{|l|}{ IgG subclasses } \\
\hline $\operatorname{lgG1}$ & $65.6 \%$ & Subclass distribution \\
\hline $\operatorname{lgG} 2$ & $28.7 \%$ & similar to plasma \\
\hline $\operatorname{lgG} 3$ & $4.2 \%$ & \\
\hline $\operatorname{lgG} 4$ & $1.4 \%$ & \\
\hline \multicolumn{3}{|l|}{ Activities } \\
\hline Anti-polio & + & present \\
\hline Anti-rubeola & + & present \\
\hline Anti-CMV & + & present \\
\hline Anti-streptolysin O & + & present \\
\hline Pyrogens & satisfactory & satisfactory \\
\hline Abnormal toxicity & satisfactory & satisfactory \\
\hline Stability (heating to $57^{\circ} \mathrm{C} / 4 \mathrm{~h}$ ) & no jelling & no jelling \\
\hline
\end{tabular}


electrophoresis and immunoelectrophoresis data are shown in Figures 2 and 3, respectively.

We describe the preparation of intravenous $5 \%$ immunoglobulins in the liquid state from a pool of human plasma from 1200 donors by the chromatographic method. The analyses performed for quality control showed that the IgG met international specifications. In the stability test involving heat-

Table 3 - Antibodies detected in liquid intravenous IgG.

$\mathrm{N}=10$.

\begin{tabular}{lll}
\hline Antibody & Method & Titer and/or unit \\
\hline Anti-polio I & Neutralization test & $1: 256$ \\
Anti-polio II & Neutralization test & $1: 128$ \\
Anti-polio III & Neutralization test & $1: 64$ \\
Anti-measles & Hemagglutination inhibition & $1: 64$ \\
Anti-rubeola & ELISA & $756 \mathrm{IU} / \mathrm{ml}$ \\
Anti-herpes & Immunofluorescence & $1: 128$ \\
Anti-cytomegalovirus & ELISA & $898 \mathrm{IU} / \mathrm{ml}$ \\
Anti-streptolysin O & Nephelometry & $716 \mathrm{IU} / \mathrm{ml}$
\end{tabular}

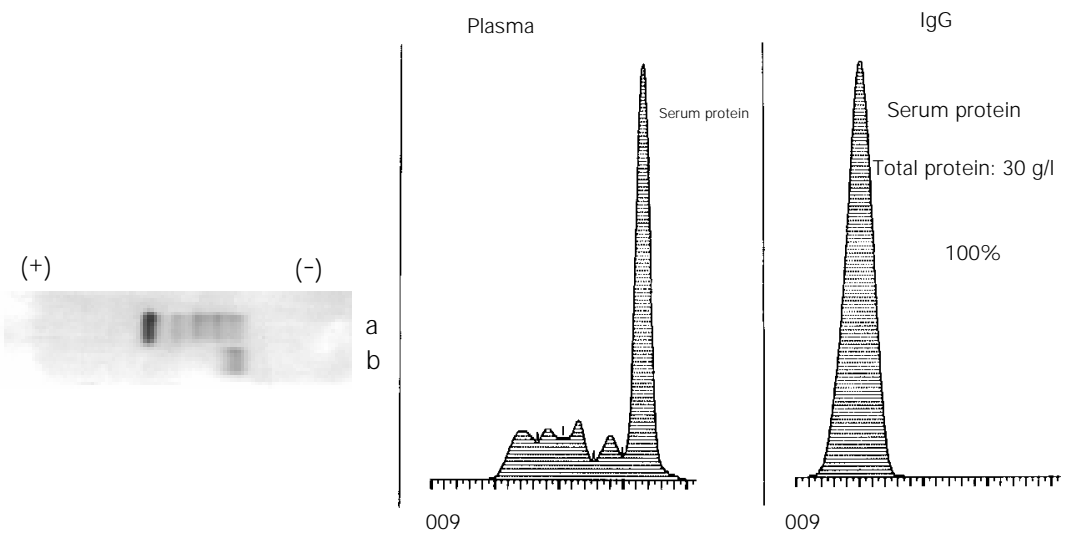

Figure 2 - Cellulose acetate electrophoresis. a, Plasma pool ( $25 \mu \mathrm{l}$ of $10 \mathrm{~g} / \mathrm{l})$; b, immunoglobulin $\mathrm{G}(25 \mu \mathrm{l}$ of $30 \mathrm{~g} / \mathrm{l})$. Protein was detected with Ponceau $\mathrm{S}$ and the data are reported as percent of total densitometer units.

Figure 3 - Immunoelectrophoresis. a, Plasma pool $(2 \mu \mathrm{l}$ of $10 \mathrm{~g} /$ I); b, immunoglobulin $\mathrm{G}(2 \mu \mathrm{l}$ of $30 \mathrm{~g} / \mathrm{l})$. Protein was detected with light green stain. ing to $57^{\circ} \mathrm{C}$ for $4 \mathrm{~h}$ there was no jelling, and in the quarantine test involving incubation in an oven at $37^{\circ} \mathrm{C}$ for 4 weeks, again there were no alterations in the $\operatorname{IgG}$ molecule.

Viral inactivation was performed with a solvent/detergent system (19), i.e., $1 \%$ Tri (n-butyl) phosphate and 1\% Triton X-100, $\mathrm{pH} 5.5$, at $35^{\circ} \mathrm{C}$ for $10 \mathrm{~h}$, which was then removed by the ion-exchange gel, CMSepharose FF. The protein aggregates generated during the process were removed by gel filtration chromatography through Sephacryl S-300 HR. Thus, the product obtained consisted mainly of the monomer, presenting only trace amounts of polymers, consistent with low anticomplementary activity, i.e., less than $1 \mathrm{CH}_{50} / \mathrm{mg} \mathrm{IgG}$.

Of the several stabilizing agents tested, glucose, sucrose and maltose, the last one at a $7.5 \%$ concentration, and $0.1 \mathrm{M}$ glycine, $\mathrm{pH}$ $5.0(12,20)$, were found to be the most appropriate. The $\operatorname{IgG}$ solution was limpid and transparent with no detectable molecular alterations even when stored for more than 2 years at 5 to $8^{\circ} \mathrm{C}$.

On the basis of in vitro and in vivo laboratory tests, we conclude that the product fully satisfies all the requirements of the Pharmacopée Européenne (1), as well as the norms of the Brazilian Ministry of Health (Regulation No. 2419 of December 17, 1996). We are awaiting the results of clinical tests currently underway to liberate the product for use.

\section{Acknowledgments}

The authors wish to thank Dr. Hiroyoshi Ito from the Japanese Red Cross, Chitose, Hokkaido, Dr. Komei Ohashi from Kaketsuken, Kumamoto, and Dr. Kentaro Nakamura from Green Cross, Osaka, for their helpful suggestions and the opportunity of training at their Plasma Fractionation Plants in Japan, and Dr. Erica Kitahara, Pharmacia Biotech, for supplying the reagents. 


\section{References}

1. Pharmacopée Européenne (1997). 2nd edn. Part II. Maisonneuve S.A., Sainte Ruffine.

2. Cohn EJ, Strong LE, Hughes J r WL, Mulford DJ , Ashworth J N, Melin M \& Taylor HL (1946). Preparation and properties of serum and plasma proteins. IV. A system for the separation into fractions of the protein and lipoprotein components of biological tissues and fluids. J ournal of the American Chemical Society, 68: 459475.

3. Mielka SI \& Gozze I (1975). Anticomplementary activity of human immunoglobulin G. I. Mechanism of the artifactual increase in anticomplementary activity of IgG during the assay. Vox Sanguinis, 29: 101-123.

4. Andersson I, Lindquist LO \& Berglöf J (1994). An improved chromatography method for production of IgG from plasma. XXIII Congress of the International Society of Blood Transfusion, The Netherlands, J uly 2-8.

5. Curling J M (1983). Separation of Plasma Proteins. Pharmacia Fine Chemicals $A B$, Uppsala.

6. Cohn EJ, Gurd FRN, Surgenor DM, Barnes BA, Brown RK, Deronaux G, Gillespie J M, Kahnt FW, Lever WF, Liu CH, Mittelman $D$, Mouton RF, Schmid $K \&$ Uroma $E$ (1950). A system for the preparation of the components of human blood: quanti- tative procedures for the separation of the protein components of human plasma. J ournal of the American Chemical Society, 72: 465-474.

7. Oncley $M$, Melin DA, Richert JW, Cameron J W \& Cross J r PM (1949). The separation of the antibodies, isoagglutinins, prothrombin, plasminogen and B1lipoprotein into subfractions of human plasma. J ournal of the American Chemical Society, 71: 541-550.

8. Barandun $S$, Kistler $P$, J eunet $F \&$ Isliker $H$ (1962). Intravenous administration of human $\gamma$-globulin. Vox Sanguinis, 7: 157-174.

9. Hässig A (1986). Intravenous immunoglobulins: pharmacological aspects and therapeutic use. Vox Sanguinis, 51: 1017.

10. Schultze HE \& Schwick G (1962). Über neue Möglichkeiten intravenöser Gammaglobulin-Applikation. Deutsche Medizinische Wochenschrift, 87: 1643-1650.

11. Sgouris J T (1967). The preparation of plasmin treated immune serum globulin for intravenous use. Vox Sanguinis, 13: 7184.

12. Fernandes PM \& Lundblad JL (1980). Preparation of a stable intravenous gamma-globulin: process design and scale-up. Vox Sanguinis, 39: 101-112.

13. Stephan W (1975). Undergraded human immunoglobulin for intravenous use. Vox Sanguinis, 28: 422-437.
14. Pappenhagen A, Lundblad J \& Schroeder D (1975). Pharmaceutical compositions comprising intravenously injectable modified serum globulin, its production and use. US Patent No. 3,903,262.

15. Schmidtberger R (1978). Amidated immune globulins and process for preparing them. US Patent No. 4,118,379.

16. Masuho $Y$, Tomibes $S$, Matsuzawa $K \&$ Ohtdu A (1977). Development of an intravenous gamma-globulin with Fc activities. I. Preparation and characterization of $\mathrm{S}$ sulfonated human gamma-globulin. Vox Sanguinis, 32: 175-181.

17. WHO Expert Committee on Biological Standardization (1982). Report of an informal meeting on intravenous immunoglobulins (human), Geneva.

18. Tanaka K, Sawatani E, Nakao HC, Dias GA \& Arashiro F (1996). An alternative column chromatographic process for the production of human albumin. Brazilian J ournal of Medical and Biological Research, 29: 185-191.

19. Horowitz B, Wieb ME, Lippin A \& Stryker $H$ (1985). Inactivation of viruses in labile blood derivatives. Transfusion, 25: 516522.

20. McCue J P, Hein RH \& Tendold R (1986). Three generations of immunoglobulin $\mathrm{G}$ preparations for clinical use. Reviews of Infectious Diseases, 8 (Suppl 4): 374-381. 


\section{A PRIVATE BRAZILIAN BIOTECHNOLOGY COMPANY \\ LEADER IN THE BRAZILIAN INSULIN MARKET}

World's fourth major insulin producer

Offers a complete line of insulins, i.e., a range of options from bovine/swine to human insulin

Operational processes run under GMP (Good Manufacturing Practices)

F.D.A./USA inspected

Has over 450 people focusing their efforts on improving services to the diabetic patient

Winner of a tender with international producers to supply human insulin to Russia

Produces a wide line of enzymes, peptones, insulin crystals, culture media and diagnostic products

Supports a strong in-house R\&D program and maintains several agreements for cooperation with research laboratories in universities and research centers

\section{DO YOU KNOW OUR COMPANY?}

If you don't know us or, if you already know us, did you realize we do all that?

Call us! It will be a pleasure to serve you. BIOBRÁS S.A. Fax: 55-31-335-79-88

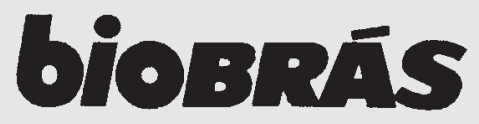

